\title{
IMPLEMENTATION OF TOTAL QUALITY MANAGEMENT (TQM) IN THE IMPLEMENTATION OF EDUCATION QUALITY CONTROL IN INFORMATION ENGINEERING STUDY PROGRAM
}

\author{
Dian Rosinawati \\ rosinawatidian@gmail.com \\ Universitas Islam Nusantara \\ Ifah Khadijah \\ ifah.khadijah@gmail.com \\ Universitas Islam Nusantara \\ Waska Warta \\ waskawarta@gmail.com \\ Universitas Islam Nusantara
}

\begin{abstract}
The main key to quality education management is how to carry out good and quality education to give birth to a generation of people who have potential, abilities, talents that grow and develop in all areas of life so that they are able to compete globally. For the implementation of quality education (quality), quality organizational management is also needed, one of which is by implementing Total Quality Management. Efforts to standardize quality and guarantee the implementation of higher education must meet quality standards in an effort to maintain and improve the quality of education nationally. In general, the definition of quality assurance in higher education is: The process of establishing and fulfilling education quality standards consistently and continuously so that customers get satisfaction. The process to ensure that the quality of graduates is in accordance with the specified/promised competencies so that quality can be consistently maintained and continuously improved.
\end{abstract}

Keywords: Quality, Management, Education, Information Enginering,

\section{A. INTRODUCTION}

The progress of a nation can be measured by the quality of human resources, an intelligent nation is a nation that is able to use educational progress to improve the quality of its nation. Education is a strategic means to improve the quality of human resources, therefore intelligent humans can be created who are ready to advance the nation.

In the thoughts of John Dewey (Achmad, 2016), "education is not a preparation of life, but it's life itself", Education is not preparation for life, but education is life itself. In line with the opinions of these experts, the Law of the Republic of Indonesia Number 20 of 2003 concerning the National Education System Chapter I Article 1 (1) also explains the definition of education, namely a conscious and planned effort to create a learning atmosphere and learning process so that students actively develop their potential. themselves, society, nation and state (Depdiknas, 2003).

The world of education requires management to regulate the organizational process in it, mentioned in the book Basics of Educational Management (Winoto, 2020) There are eight substantive components in education management, namely: 1. Curriculum and student learning 
management 2. Student management 3. Infrastructure management (Sarpras) 4. Public Relations Management 5. Human Resource Management or Education Personnel Management (Educators and Non Educators) 6. Financing Management 7. Administrative Management 8. Guidance and Counseling Management. The components in education management are interrelated and are important in the teaching and learning process.

These various components in educational activities must be managed properly, including those related to the teaching and learning process, which are stated as follows:

\section{Curriculum Management and student learning}

The foundation of education is a curriculum where the curriculum is used as a reference for teachers to determine appropriate learning strategies in the classroom. According to the UPI Lecturer Team (2011: 191) curriculum management is a cooperative, comprehensive, systemic, and systematic curriculum management system in order to realize the achievement of curriculum goals. The scope of curriculum management includes planning, implementing, and evaluating curriculum activities kegiatan.

2. Student Management

Student management is an effort to regulate students starting from students being accepted into school until students graduate from school. Meanwhile, school-based student management is student management that emphasizes the four pillars of school-based management, namely: quality, independence, community participation and transparency (Imron, 2012: 6). The general objective of school-based student management is to regulate student activities so that these activities support the teaching and learning process in schools effectively and efficiently. According to Imron (2012: 18) in detail the scope of student management is as follows: (1) student planning, (2) student acceptance, (3) new student orientation, (4) regulates the presence and absence of students at school, (5) regulate the grouping of students, (6) regulate the evaluation of students, (7) regulate the increase in the level of students, (8) regulate students who transfer and drop out, and (9) regulate the code of ethics of student discipline.

3. Management of Educational Facilities and Infrastructure

Learning process activities in schools cannot run effectively and efficiently without being supported by adequate learning facilities in schools. The existing facilities and infrastructure in schools need to be arranged so that they are suitable for use in supporting the learning process in schools starting from the procurement stage to the elimination of school facilities and infrastructure. School facilities include all equipment and supplies that are directly used in the educational process at school. For example: school buildings (school buildings), rooms, tables, chairs, props, and other direct learning support tools while infrastructure are all components that indirectly support the teaching and learning process or education in schools. For example: the road to school, the school yard, school rules, and so on.

4. Management of Educators and Education Personnel

Educators and education staff need to be managed and regulated properly so that the learning process and school administration can run effectively and efficiently. Management of educators and education is an activity that must be carried out starting from the educators and educational staff entering the educational organization until it finally stops through the process of human resource planning, recruitment, selection, placement, compensation, awards, education and training/development, and termination. The existence of management of educators and education personnel is to facilitate the management of staffing activities in schools. 
How an educational institution leader carries out his duties to achieve goals effectively and efficiently is manifested in the four substances of education management as stated by George $R$. Terry in the book Principles of management, known as POAC Management, namely Planning, Organizing, Actuating and Controlling. The basic concept of management is a work efficiency movement that results in lower costs and increases productivity, quality, work income and employee morale (Terry, 2010).

George R. Terry's classical management theory is still acceptable to practitioners in completing work most efficiently, because in its application it is complete, where each element has an influence and benefit that is truly able to support all aspects. The main key to quality education management is how to carry out good and quality education to give birth to a generation of people who have potential, abilities, talents that grow and develop in all areas of life so that they are able to compete globally. For the implementation of quality education (quality), quality organizational management is also needed, one of which is by implementing Total Quality Management.

The application of quality that was previously developed in the industrial world can actually be applied in the world of education. (Sallis, 2014) argues that the application of TQM which was previously used in the industrial world does not mean that business methods are superior to educational applications, more than that, the business world can learn from the methods applied in various schools, colleges and universities. The quality of higher education is currently more directed at the quality of graduates (Outcome Base Education). That is to get graduates who meet the expectations of society and are able to provide benefits and color a positive life in society.

The application of TQM in Higher Education cannot be separated from one of the management components, namely Education Quality Control, where this form of supervision and quality control is an activity of the Higher Education Tridharma that must be carried out consistently and sustainably so that internal and external stakeholders obtain satisfaction.

In supporting the strengthening of higher education accreditation by the National Accreditation Board for Higher Education (BAN-PT), the implementation of education quality control was chosen through internal quality control / AMI (Internal Quality Audit) in the author's environment, namely at the Nusantara Islamic University so that the writing of this article is focused on discussing on "Implementation of Total Quality Management (TQM) in the Implementation of Education Quality Control in Informatics Engineering Study Program".

The study in this article assumes that the implementation of TQM (Total Quality Management) in the Informatics Study Program has been carried out through educational supervision activities by the Internal Quality Audit (AMI) in accordance with the University's SPMI to support the strengthening of higher education accreditation by the National Accreditation Board for Higher Education (BAN-PT).

\section{B. METHOD}


The writing method used in this paper, namely by conducting a literature review or literature study from relevant sources, such as books and journals, Laws and Higher Education Internal Quality Assurance Standards (SPMI) (Sugiyono, 2010).

\section{RESULT AND DISCUSSION}

\section{Implementation of Total Quality Management (TQM) in Higher Education}

TQM (Total Quality Management) or what we usually know as Integrated Quality Management is an integrated quality improvement concept in the field of management. The factors that cause the low quality of higher education are due to the lack of optimal management of higher education, limited facilities and learning support facilities, and there are still human resources that do not meet the requirements (Muslim \& Sururin, 2018).

TQM in the world of higher education is related to the results of the quality of the student experience, where students are primary customers, so maximum management is needed to provide academic and non-academic service guarantees to students. Higher education products in the form of higher education services consist of curriculum services and research services, community service services, administrative services, and extracurricular services.

As part of the Internal Quality Assurance System (SPMI) which must be implemented based on Law No. 12 of 2012 concerning Higher Education and Permenristekdikti No. 62 of 2016 concerning the higher education quality assurance system, Internal Quality Audit (AMI) is basically a necessity for a study program or higher education institution to be able to determine the achievements and non-achievements of the national standards of higher education that it implements. Armed with the data from the AMI results, a study program and higher education institution can determine improvements and or improvements to any quality standards that have been implemented so that the implementation of higher education takes place efficiently and effectively.

Total Quality Management or TQM, according to Edward Sallis (Saril, 2019) is a philosophy of continuous improvement, which can provide educational institutions with a set of practical tools to meet the needs, wants and expectations of their customers, now and in the future. The word total (integrated) emphasizes that everyone in the organization must be involved in efforts to make continuous improvement. The word management applies to everyone, because everyone in an institution, regardless of status, has a role as a manager for their respective responsibilities. Total Quality Management is a desire to always try to do everything "always good from the start".

Kotler (1997) in (Muslim \& Sururin, 2018), defines TQM as an organizational approach that continuously improves overall quality in organizational processes, products, and services. Organizations that use TQM strive to make continuous improvements in order to win the competition in the upcoming global era. Efforts are intended in the form of steps to improve continuous improvement, such as:

1. Customer focus;

2. Improvement process; and

3. Total involvement (De Toro \& Tenner, $2000: 32$ ).

TQM is a management system that promotes quality as a business strategy and is oriented to 
customer satisfaction by involving all members. Total quality approach in (Muslim \& Sururin, 2018) can only be achieved by paying attention to the characteristics of TQM, the following:

a. Focus on customers, both internal and external customers

b. Have a high obsession with quality

c. Using a scientific approach in decision making and problem solving

d. Have a long term of commitment

e. Requires teamwork

f. Continuously improve processes

g. Organizing education and training

h. Provides controlled freedom kebebasan

i. Have a unity of purpose

j. There is employee involvement and empowerment (Tjiptono, $2000: 19$ )

2. Implementation of Education Quality Control in Higher Education

Internal Quality Audit is not an assessment/assessment but rather a match between the implementation and the planning of an activity/program, through its implementation. There are three stages in carrying out supervision (Neagley \& Evans, 1980).

\section{a. Setting implementation standards}

Determination of standards includes criteria for all layers of work (job performance) contained in an organization. The established standards must be clear, measurable and contain a specific time limit. Standards are the criteria for measuring the performance of work. And these criteria can be quantitative or qualitative.

\section{b. Measurement of results / execution of work}

Correction methods and techniques can be seen/implemented through management functions, from planning, as a benchmark for all management processes. Furthermore, organizing, checking whether the organizational structure is in accordance with the standards, duties and obligations have been well understood and whether there is a need to restructure members.

\section{c. Determining Deviations or Deviations and Taking Corrective Actions}

This phase will be carried out in the event of deviations and the implementation of improvements as actions taken to adjust the results of work that deviate to conform to the standards or previously determined. If deviations occur, improvements cannot be made immediately but adjust to the results of work that are in accordance with standards or plans. Furthermore, the most important thing is that reporting must be carried out so that deviations can be identified immediately and preventive actions can be taken as soon as possible so that all work implementations are carried out according to plan.

Implementation and Results of Internal Quality Audits include; Auditee (Unit of the organization/Prodi which is the object of AMI implementation), Auditor (another unit of higher education organization that implements AMI), LPMI (Internal Quality Assurance Institution 
responsible for the implementation of AMI), and Leader (Rector/Leader of the Higher Education Institution)

3. Implementation of Total Quality Management (TQM) in the Implementation of Education Quality Control in Informatics Engineering Study Program

The implementation of Total Quality Management (TQM) in higher education is contained in the SPMI (Internal Quality Assurance System) which must be carried out on the basis of mutual understanding and responsibility to prioritize the efficiency of higher education and improve the quality of the higher education process. SPMI is intended to supervise the implementation of higher education by the universities themselves on an ongoing basis.

Based on Law Number 20 of 2003 concerning the National Education System and Government Regulation Number 19 of 2005 concerning National Education Standards (SNP), it is stated that quality assurance is mandatory both internally and externally. Through Permendikbud No. 19 of 2005 concerning SNP, it has been updated with Permendiknas number 49 of 2014. Furthermore, the definition of a higher education quality assurance system is "a systematic activity to improve the quality of higher education in a planned and sustainable manner". The higher education quality assurance system consists of 2 types, namely the internal quality assurance system (SPMI) whose implementation depends on the respective institutions and the external quality assurance system (SPME) consisting of accreditation from BAN-PTSPMI which must be carried out by universities internally to realize its vision and mission, as well as to meet the needs of stakeholders through the implementation of the Tridharma of Higher Education

The process of implementing SPMI activities has been regulated in Article 5 of Permenristekdikti No. 62 of 2016 with a cycle of activities consisting of: a) Determination of Higher Education Standards; b) Implementation of Higher Education Standards; c) Evaluation of the implementation of Higher Education Standards d) Control of the implementation of Higher Education Standards; and e) Improvement of Higher Education Standards.

Internal Quality Audit is an independent and objective Quality assurance and consulting activity. This activity is designed to: 1 . Provide added value and improve the operational performance of higher education institutions. 2. Knowing that efforts to maintain, improve academic quality and standards have been appropriate and effective. 3. Identify the scope of continuous professional improvement and development based on self-evaluation. The following is the implementation of AMI (Internal Quality Audit in Informatics Engineering Study Program as the implementation of Quality Control in Higher Education, with the following implementation results:

\section{a. Background}

The Uninus Quality Assurance Institute (LPM) as the institution responsible for the implementation of quality assurance within the Uninus environment, has implemented AMI since 2017 in stages starting from the study program level. AMI is applied to all aspects of standard education, research, and community service in accordance with Law No. 5 of 2005 concerning National Education Standards, Permenristekdikti no. 44 of 2015 concerning National Higher Education Standards, and then adjusted to the assessment matrix based on 9 criteria in the study program accreditation instrument contained in PT Ban Regulation No. 5 of 2019. 
The Informatics Engineering Study Program has implemented national higher education standards and higher education standards in the fields of education, research, and community service along with monitoring during its implementation. Therefore we need a follow-up in the form of an evaluation through AMI, in order to know the achievement of the quality standards that have been applied. Apart from that, the importance of implementing AMI for the Informatics Engineering Study Program is for the sake of improvement/improvement of the quality and service quality to the academic community in the Informatics Engineering Study Program environment.

In general, the Informatics Engineering Study Program has made improvements to the findings of the Internal Quality Audit (AMI) in 2019. The results and recommendations of the previous AMI have been widely followed up so that the majority of existing data and evidence have begun to increase compared to the previous year. However, due to the change in the indicators for the success of the study program management, which was originally based on 7 standards to 9 criteria, there are many documents that have not been fulfilled. Starting from the number of standard operating procedures, their implementation, monitoring, to the evaluation and follow-up stages, they have not been fully owned and implemented.

Improvements that have been made by study programs, especially on educational criteria, are learning outcomes standards related to graduate profiles; standard of learning content related to curriculum evaluation, course distribution, number of credits, and completeness of RPS-RTM for each course; the learning process is related to the monitoring and evaluation of the learning process; as well as learning assessment standards related to monitoring student grades. The next improvement is in the Human Resources criteria, namely the standards of lecturers and education staff related to efforts to reduce the number of extraordinary lecturers, increase the number of permanent lecturers, and provide education staff with qualifications and competencies according to study program needs. On the standard of infrastructure, the improvements made were related to the provision of study programs leadership rooms, lecturer rooms, as well as simple improvements to laboratory feasibility.

In the implementation of the AMI in 2020, there were several observational findings, including those related to the formulation of the VMTS which had not been accompanied by an evaluation process even though it had involved stakeholders in its formulation; the availability of incomplete access to physical documents includes a recapitulation of fund management (education, research, and PKM), the number of studies, the number of articles, the number of proceedings, and the number of PKM. UPPS and Universities need to solve this problem urgently; unavailability of research roadmap and study program PKM. Nevertheless, there are 6 (six) findings/good practices applied by study programs in the field of education, especially in monitoring the evaluation of the learning process.

\section{b. Internal Quality Audit Objectives}

The objectives of implementing this quality audit are::

1) To examine the compliance of the Informatics Engineering study program with the obligation to implement the National Higher Education Standards and the Higher Education Standards of the Nusantara Islamic University.

2) Assessing the level of compliance of the Informatics Engineering Study Program with the obligation to carry out quality assurance. 
3) Researching whether the education administration in the Informatics Engineering Study Program is based on competencies derived from BAN PT Regulation No. 5 of 2019 concerning IAPS. Matrix for undergraduate program assessment of 9 BAN-PT accreditation criteria.

4) To ensure that the teaching process in the Informatics Engineering study program is carried out based on applicable rules/standards.

c. Measured Components

The implementation of the Internal Quality Audit at the Informatics Engineering Study Program at the Islamic Nusantara University is focused on implementing the national higher education standards and the Uninus higher education standards, which are grouped into 9 criteria according to the BAN-PT accreditation assessment matrix, namely: vision and mission; governance, governance and cooperation; student faculty and education staff; finance and infrastructure; education; research; community service; as well as outside.

d. Audit Implementation Method

The Internal Quality Audit (AMI) process includes inspection, assessment and evaluation of auditee documents followed by field visits. The inspection process begins with an audit of documents on the internal quality assurance monitoring file that has been carried out by the Informatics Engineering Study Program in the last year, followed by the preparation of a checklist.

The AMI process is continued with field visits for process and document verification activities for auditees. The determination of the schedule of activities is determined by the Quality Assurance Institute of the Islamic Nusantara University. The audit was carried out by means of a direct visit by two auditors to the Informatics Engineering Study Program at the Faculty of Engineering, Universitas Islam Nusantara. Interviews were conducted with the Secretary of Study Programs, Quality Assurance Unit (UPM), Lecturers of Study Programs, Secretary of Study Programs, and education staff as auditees. In addition to being interviewed, Auditi was also asked to show physical evidence in the form of documents and performance records, and was asked to show the infrastructure owned by the study program, such as: lecture rooms, practicum rooms, study program leadership rooms, and lecturer rooms.

During the field visit, the auditor invites the auditee to confirm each statement item contained in the audit instrument along with the supporting documents. After the auditee submits the confirmation, the auditor conveys the results of the consideration of the value of each item of the instrument to the auditee so that each value given by the auditor is the result of mutual agreement.

At the end of the field visit, the auditor conveys the results of the final calculation and the final score achieved to the auditee, to then confirm its objectivity to the auditee. In addition, the auditor submits the findings and recommendations to the auditee for mutual approval. The results of the examination of documents and audit records are then entered into the following formats: AMI 2019 entry and calculation, Good Findings, and Corrective Action Submission (CAR).

Furthermore, Good Findings and Corrective Action Proposals are submitted to the auditee for immediate follow-up through Management Review Meetings (RTM) and Follow-Up Meetings (RTL), in stages, in the Informatics Engineering Study Program which is coordinated by the Quality Assurance Unit (UPM) of Study Program, followed by RTM -RTL at the faculty level is coordinated by the Faculty Quality Assurance Group (GPM), and finally the RTM-RTL at the university level is coordinated by the Quality Assurance Institute (LPM). 
Meanwhile, the auditor prepares the AMI Results report based on all AMl findings and calculations. The report is made in duplicate to be submitted to LPM and the auditee.

\section{CONCLUSIONS}

Efforts to standardize quality and guarantee the implementation of higher education must meet quality standards in an effort to maintain and improve the quality of education nationally. In general, the definition of quality assurance in higher education is: 1 . The process of establishing and fulfilling education quality standards consistently and continuously so that customers get satisfaction. 2. The process to ensure that the quality of graduates is in accordance with the specified/promised competencies so that quality can be consistently maintained and continuously improved. In other words, a university is said to be of high quality if it is able to establish and realize the campus vision through the implementation of its mission (deductive aspect), and is able to meet the needs/satisfy stakeholders (inductive aspect), namely the needs of students, the community, the world of work and professionals.

\section{References}

Achmad, S. (2016). PENDIDIKAN KARAKTER DAN KEMAJUAN NEGARA: STUDI PERBANDINGAN LINTAS NEGARA. 1, 24.

De Toro, I., \& Tenner, A. (2000). Total Quality Management: Three Steps. To Continuous Improvement. Addison-Wesley.

Depdiknas. (2003). Undang-Undang Nomor 20 Tahun 2003 Tentang Sistem Pendidikan Nasional. Depdiknas RI.

Muslim, M., \& Sururin. (2018). Total Quality Management (TQM) di Perguruan Tinggi. 21(2), 119130.

Neagley, R. L., \& Evans, N. D. (1980). Handbook for Effective Supervision of Instruction. Prentice-Hall, Inc.

Sallis, E. (2014). Total quality management in education: Third edition. In Total Quality Management in Education: Third Edition (Third edit). https://doi.org/10.4324/9780203417010

Saril, S. (2019). Total Quality Management (Tqm) Sebagai Wujud Peningkatan Mutu Pendidikan. Adaara: Jurnal Manajemen Pendidikan Islam, 9(2), 963-972. https://doi.org/10.35673/ajmpi.v9i2.430

Sugiyono. (2010). Metode Penelitian Pendidikan Pendekatan Kuantitatif, kualitatif, dan R\&D. Alfabeta.

Terry, G. R. (2010). Prinsip-Prinsip Manajemen. PT. Bumi Aksara.

Tjiptono, F. (2000). Manajemen Jasa. Andi Offset.

Winoto, S. (2020). Dasar-Dasar Manajemen Pendidikan. Book, 1(ISBN 978-623-7177-47-0), 290 hal. https://doi.org/10.1088/1751-8113/44/8/085201 